\title{
The Obligations of China and the Role of International Law in the Context of the Coronavirus Pandemic
}

\author{
Xinxiang Shi" \& Xiaoou Zheng ${ }^{* *}$
}

This short article examines whether China has incurred responsibility for violating a general due diligence obligation in customary international law or specific obligations under the WHO's International Health Regulations and the WHO Constitution in a context of Covid-19. It is submitted that due diligence is merely a notion to describe a primary obligation, or a standard by which a particular primary obligation is assessed. It cannot serve as the basis for holding a State responsible. Regarding the WHO regime, actions taken by China after December 2019 neatly fit into the staggered requirements of Articles 6 and 7 of the International Health Regulations, which do not set out clear standards for the evaluation of a health emergency. On a more general level, we reflect upon the role of international law in global pandemic control and caution against the politicization of international health law.

\section{Keywords}

State Responsibility, Due Diligence, International Health Regulations, Covid-19, China

* Lecturer of International Law at Dalian Maritime University, China. B.A. (Shanghai U.), LL.M. (CUPL), Ph.D. (Edinburgh). ORCID: https://orcid.org/0000-0001-7921-7656. This work was supported by the China Postdoctoral Science Foundation (Project No. 2020M680923). The views reflected in this article, however, are the author's own. The author may be contacted at: xinxiang-shi@outlook.com /Address: 1, Linghai Rd, Ganjingzi District, Dalian, P.R. China.

** Assistant Professor of International Law at Xiamen University, China. B.A. \& LLM. (Zhongnan U. of Economics \& Law), MSc. \& Ph.D. (Edinburgh). ORCID: https://orcid.org/0000-0002-9577-1881. The views reflected in this article are the author's own. The author may be contacted at: xiaoouzheng@xmu.edu.cn/Address: 422 Siming S Rd, Siming District, Xiamen, Fujian, P.R. China, 361005.

All the websites cited in this article were last visited on April 5, 2021. 


\section{Introduction}

Since its outbreak in December 2019, Covid-19 has caused enormous human suffering and economic loss around the world. Although the scientific community is making remarkable efforts globally and domestically to combat the crisis, ${ }^{1}$ in the political arena, there are increasing voices of blaming China, the state where the first case of the disease was reported for the pandemic. The US politicians have repeatedly called, without evidence and against advices of the scientific community, Covid-19 "Wuhan virus" or "China virus," and are allegedly mulling proposals for demanding financial compensation from China. ${ }^{2}$ The Australian government has further called for international investigation into China's handling of the outbreak. ${ }^{3}$ Likewise, the International Council of Jurists and All India Bar Association urged the United Nations Human Rights Council to seek reparations from China for "surreptitiously developing a biological weapon capable of mass destruction."4

International law scholars have been quick to follow these demands, proposing various arguments in support of the efforts to hold China responsible. Most of these arguments follow the line that either China's omission/negligence in handling the outbreak has violated a general obligation of due diligence toward other states, ${ }^{5}$ or China has violated its specific duties under the International Health Regulations (IHR) of the World Health Organization (WHO). ${ }^{6}$

The primary purpose of this research is to examine and rebut these arguments and, on that basis, reflect upon the role of international law in global pandemic control. This paper is composed of four parts including Introduction and Conclusion. Part two will

1 The Department of Global Communications, UN Mobilizes Global Cooperation in Science-based COVID-19 Responses, Apr. 7, 2020, https://www.un.org/en/un-coronavirus-communications-team/un-mobilizes-globalcooperation-science-based-covid-19-responses.

2 J. Stein, C. Leonnig, J. Dawsey \& G Shih, U.S. Officials Crafting Retaliatory Actions Against China Over Coronavirus As President Trump Fumes, WASH. Post, May 1, 2020, https://www.washingtonpost.com/business/2020/04/30/trumpchina-coronavirus-retaliation.

3 S. Dziedzic, Australia Started A Fight With China Over An Investigation Into COVID-19-Did It Go Too Hard?, ABC NEws, May 20, 2020, https:/www.abc.net.au/news/2020-05-20/wha-passes-coronavirus-investigation-australia-whatcost/12265896.

4 See India Drags China to International Court for COVID-19 War, GreatGameIndia: J. on GeoPolitics \& Int'L ReLATIONs, Apr. 4, 2020, https://greatgameindia.com/india-drags-china-to-international-court-for-covid-19-war.

5 A. Coco \& T. Dias, Part I: Due Diligence and COVID-19: States' Duties to Prevent and Halt the Coronavirus Outbreak, EJIL:Talk!, Mar. 24, 2020, https://www.ejiltalk.org/part-i-due-diligence-and-covid-19-states-duties-toprevent-and-halt-the-coronavirus-outbreak.

6 R. Bagares, China, International Law, and COVID-19, Inquirer.Net, Mar. 22, 2020, https://opinion.inquirer. net/128226/china-international-law-and-covid-19. International Health Regulations [2005] W.H.A. Res. 58.3, https:// www.who.int/publications/i/item/9789241580496. 
discuss the potential obligations of China under general international law and the IHR. ${ }^{7}$ Part three will look into more general issues of the role of international law in global pandemic management and cautions against the politicization of international health law.

\section{Has China Violated Its International Obligations?}

\section{A. Due Diligence Obligation in International Law}

Due diligence, as a legal concept of international law, has emerged and developed largely within the regime of state responsibility. Historically, this concept has mainly been discussed in the context of a state's duty to protect the rights of foreign states and their nationals within its territory from the activities of private individuals. ${ }^{8}$ Normative developments since the early twentieth century have seen the application of "due diligence" being extended to international law areas encompassing environmental law, diplomatic law, and humanitarian law. As a result, "due diligence" is widely perceived as a general principle of international law. ${ }^{9}$

A more controversial issue is China's responsibility for its alleged failure to handle the coronavirus pandemic. It depends on whether, as a corollary of the abovementioned principle, there exists a general due diligence obligation that requires a state to take appropriate measures to ensure that activities within its boundary do not cause harm to other states. The International Law Association Study Group on Due Diligence in International Law, for instance, has concluded in its final report that there is a "broader obligation of due diligence" that underlies the "more specific instances of due diligence" and that, as a default rule, can be "triggered in operation if no more specific elaboration of due diligence or stricter standard is in

7 Issues relating to a State's obligations towards individuals, such as whether quarantine measures infringe certain human rights, are beyond the scope of this article.

8 In the Wipperman Case between the US and Venezuela, e.g., the arbitral tribunal stated that no state is responsible for acts of private individuals in its territory "as long as reasonable diligence is used in attempting to prevent the occurrence or recurrence of such wrongs.” See Wipperman Case (U.S. v. Venez) (1887), reprinted in, 3 HistoRY AND DigEST OF the International Arbitrations to Which the United States Has Been a Party 3041 (J. Moore ed., 1898). Moore indicated in S.S. Lotus that: "It is well settled that a State is bound to use due diligence to prevent the commission within its dominions of criminal acts against another nation or its people." See S.S. "Lotus (Fr. v. Turk.), Judgment, 1927 P.C.I.J. (ser. A), No. 10 at 88 (Sept. 7).

9 T Koivurova, Due Diligence, Max Planck Encyclopedia of Public International LaW (R. Wolfrum ed., 2010), 12 , https://opil.ouplaw.com/view/10.1093/law:epil/9780199231690/law-9780199231690-e1034?prd=EPIL. 
existence." ${ }^{\text {"10 }}$ For the authors holding a similar position, this general obligation of "due diligence" would be helpful in dealing with new challenges of international law and ensuring that all states abide by a minimum standard of conduct when no specific primary rule exists. ${ }^{11}$ One such new challenge comes from cyberspace. Without international treaties regulating interstate cyber activities as well as the paucity of state practice accompanied by opinio juris, the general obligation of due diligence in international law means that states must bear responsibility for failing to take appropriate measures to prevent a cyber operation within their jurisdiction from causing serious consequences for other states. ${ }^{12}$ If following this reasoning, China should be responsible for its failure to exercise due diligence in containing Covid-19 even in the absence of any international norm directly prescribing the obligation of states for pandemic control.

Proponents of this general obligation of due diligence invariably rely on the dictum of the International Court of Justice (ICJ) in the Corfu Channel case that it is "every state's obligation not to allow knowingly its territory to be used for acts contrary to the rights of other states." "In the Corfu Channel case, the ICJ did not accept the view that Albania had laid the mines or connived with Yugoslavia to carry out the operation, but found that the mines could not have been laid without the knowledge of the Albanian Government. Based on this recognition, the Court stated that Albania had violated its obligation to take "all necessary steps immediately to warn ships near the danger zone, especially those that were approaching that zone."14

This obligation is based on "certain general and well-recognized principles" which include, besides the abovementioned dictum, "elementary considerations of humanity" and "the principle of the freedom of maritime communication." 15 Even though these principles are clearly applied, it is questionable whether they evince a free-standing obligation of due diligence in customary international law. If anything, the term "rights" in the ICJ statement clearly points to the existence of primary

10 ILA Study Group on Due Diligence in International Law, Second Report (July 2016), https://www.ila-hq.org/index. php/study-groups.

11 Id. at 47. See also L Chircop, A Due Diligence Standard of Attribution in Cyberspace, 67 InT'L \& ComP. L. Q. 650 (2018). Furthermore, Riccardo refers to due diligence as "a general rule," but points out that fragmented development of this rule in specific areas means that the rule is losing its characteristics as a general norm. See R Pisillo-Mazzeschi, The Due Diligence Rule and the Nature of the International Responsibility of States, 35 German Y.B. INT'L L. 45 (1992).

12 M. Schmitt (ed), Tallinn Manual 2.0 on the International Law Applicable to Cyber Operations 30-50 (Rules 6 and 7) (2017); C Patrick, Debugging the Tallinn Manual 2.0's Application of the Due Diligence Principle to Cyber Operations, 28 WASH. INT'L L. J. 581 (2019); Chircop, $i d$.

13 Corfu Channel (U.K. v. Alb.), Judgment, 1949 I.C.J. Rep 4, at 22 (April 9).

14 Id. at 23.

15 Id. at 22. 
rules of international law, which, in light of the Court's emphasis on the elementary considerations of humanity and the freedom of maritime communication, pertain to innocent passage through straits used for international navigation ${ }^{16}$ and protection of foreign nationals within a state's territory. ${ }^{17}$ This means that the Court has in fact understood due diligence not as a general obligation but as a legal concept or standard by which the contents of a state's primary obligations vis-à-vis specific rights of another state may be described or determined. ${ }^{18}$

This understanding is characteristic of the Court's subsequent jurisprudence. In cases where due diligence is at issue, the ICJ invariably examines the concept by referring to a specific treaty or customary rule. Notably, the Court in the Genocide Convention case spoke of the critical importance of the "notion of due diligence" in assessing the obligation to prevent genocide under Article 1 of the Genocide Convention, ${ }^{19}$ and specifically refrained from establishing "a general obligation on states to prevent the commission by other persons or entities of acts contrary to certain norms of general international law. ${ }^{20}$ Similarly, in Armed Activities, the ICJ used the term "duty of vigilance" to describe Uganda's obligation under Article 43 of The Hague Regulations of $1907 .^{21}$ The Court maintained that an occupying power "shall take all the measures in his power to restore, and ensure" that applicable rules of international human rights law and international humanitarian law are respected. ${ }^{22}$ In the Pulp Mills case, regarding environmental protection, the ICJ adjudicated that due diligence should be exercised by the parties in fulfilling their specific obligations

16 On a later stage, the Court spoke of the generally recognized international custom that "states in time of peace have a right to sending their warships through straits used for international navigation between two parts of the high seas without the previous authorization of a coastal State, provided that the passage is innocent." See id. 28.

17 One of the classic expressions of this duty of protection can be found in Huber's dictum in The Island of Palmas Case. See The Island of Palmas Case (U.S. v. Neth.), II R.I.A.A. 829, 8 (Perm. Ct. Arb. 1928), https://pca-cpa.org/en/ cases/94. Commenting on Corfu Channel, Heathcote draws a distinction between 'rights' and 'interests,' and indicates that: "it is only in relation to established rights that an obligation of due diligence is owed by one state to another." See S. Heathcote, State Omissions and Due Diligence: Aspects of Fault, Damage and Contribution to Injury in the Law of State Responsibility, in The ICJ and the Evolution of International Law: The Enduring Impact of the Corfu Channel Case 299 (K. Bannelier et al. eds., 2012).

18 Judge Badawi Pasha, while disagreeing with the Court's finding that Albania was aware of the mines in its waters, pointed out that a general obligation which requires coastal States to exert reasonable vigilance along their coast "does not exist and cannot exist." See Corfu Channel (U.K. v. Alb.), 1949 I.C.J. Rep. 4, at 65 (April 9). (Dissenting Opinion by Judge Badawi Pasha).

19 Application of the Convention on the Prevention and Punishment of the Crime of Genocide (Bosn. \& Herz. V. Serb. \& Montenegro), Judgment, 2007 I.C.J. Rep. 43, 430 (Feb. 26).

$20 \quad I d \cdot \llbracket 429$.

21 Armed Activities on the Territory of the Congo (D.R.C. v. Uganda), Judgment, 2005 I.C.J. Rep. 168, 246 (Dec. 19).

22 Id. 178. 
under a bilateral treaty. ${ }^{23}$ The ICJ recognized that the principle of prevention derives from due diligence that is required by a state in its territory. ${ }^{24}$ However, the Court restricted the application of this principle to the field of environmental protection, where there is a longstanding customary rule that states are obligated to ensure the activities within their jurisdiction and control respect the environment of other states or areas beyond national control. ${ }^{25}$ This decision was largely followed by the ICJ in the Costa Rica v. Nicaragua case. ${ }^{26}$

Jurisprudence of other international tribunals points in the same direction. The Alabama Arbitration, which is still perceived as relevant in articulating the scope of due diligence principle, was decided on the basis of a treaty provision that imposed a duty on the parties to exercise due diligence in their jurisdictions to prevent violation of the law of neutrality by private actors. ${ }^{27}$ In Seabed Mining Advisory Opinion, the International Tribunal for the Law of the Sea (ITLOS) examined due diligence obligations contained in Article 139 and Annex II, Article 4(4) of the United Nations Convention on the Law of the Sea (UNCLOS), which generally requires a state party to take appropriate measures to ensure that activities of private enterprises or individuals regarding the Area ${ }^{28}$ comply with the UNCLOS. ${ }^{29}$ In a similar vein, the International Centre for the Settlement of Investment Disputes (ICSID), in AAPL v Sri Lanka, approached the concept of due diligence by first establishing the existence of a host state's primary obligation to provide adequate protection to foreign investors in

23 Pulp Mills on the River Uruguay (Arg. v. Uru.), Judgment, 2010 I.C.J. Rep.14, $1 \uparrow 187 \& 197$ (Apr. 20).

$24 \quad I d . \uparrow 101$.

25 Legality of the Threat or Use of Nuclear Weapons, Advisory Opinion, 1996 I.C.J. Rep. 226 \ 29 (July 8). See ILC, Report on the Work of its Fifty-third Session (23 April-1 June and 2 July-10 August 2001), at 153 (art. 30), U.N. Doc. A/56/10 (2001); Declaration of the United Nations Conference on the Human Environment, princ. 21, UN Doc. A/ CONF.48/14/Rev1 (1972).

26 Certain Activities carried Out by Nicaragua in the Border Area (Costa Rica v. Nicar.), Judgment, 2015 I.C.J. Rep. 665, ๆ 104 (Dec. 16). For details, see N McDonald, The Role of Due Diligence in International Law, 68 INT'L \& Comp. L. Q. 1044-7 (2019).

27 Alabama Claims of the United States of America against Great Britain [1872] The Tribunal of Arbitration Established by Article I of the Treaty of Washington RIAA Vol XXIX 125-134. Another classic case, Trail Smelter, is of dubious relevance. The arbitral tribunal in this case held Canada responsible for the activities of a private company which polluted the environment of the US. Instead of examining the appropriateness of the measures taken by Canada to prevent the damage, however, the tribunal based its decision largely on the seriousness of the consequence. Thus, the authors have argued that Trail Smelter is in fact a matter of strict liability. See, e.g., R. Barnidge JR., The Due Diligence Principle under International Law 8 InT'L Comm. L. Rev. 102 (2006).

28 UNCLOS art 1(1). It provides: "For the purposes of this Convention, "Area" means the seabed and ocean floor and subsoil thereof, beyond the limits of national jurisdiction."

29 Responsibilities and Obligations of States Sponsoring Persons and Entities with Respect to Activities in the Area, Case No. 17, Advisory Opinion of Feb. 1, 2011, ITLOS Rep. 2011, 10, https://www.itlos.org/fileadmin/itlos/documents/ cases/case_no_17/adv_op_010211.pdf. 
customary international law. ${ }^{30}$

The fact that these international courts or tribunals have always articulated the meaning of due diligence by reference to a specific primary rule of international law makes it difficult to argue that there exists a free-standing obligation of due diligence. Rather, these decisions confirm the above reading of the ICJ dictum in Corfu Channel that due diligence is either a notion to describe a primary obligation, or a standard by which a particular primary obligation is assessed. The UN International Law Commission (ILC) explains in its commentaries on the Draft Articles on Responsibility of States for Internationally Wrongful Acts (hereinafter Draft Articles on State Responsibility) that contents of due diligence vary from one context to another and are thus matters "for the interpretation and application of the primary rules engaged in the given case." ${ }^{\text {, }}$ The question may then arise whether the alleged responsibility of China for its handling of the outbreak could be based on certain primary rules of international law.

\section{B. The WHO and the IHR}

The WHO, with its unrivaled competence and expertise in international public health, has been at the center of international health law for more than half a century since its inception in 1948. It is thus natural that, so far, most accusations against China have been made within the WHO regime. Notably, it has been argued that China has violated its duties under Articles 6 and 7 of the IHR, adopted in 2005 by the WHO Health Assembly. ${ }^{32}$

According to Article 6(1) of the IHR, each state party shall assess events occurring within its territory using a specific decision instrument and notify the WHO within 24 hours of those events that may constitute a public health emergency of international concern as well as any health measure implemented in response to those events. ${ }^{33}$ Article 6(2) goes on to require a state that has made the notification to continue to communicate relevant information to the WHO in a timely, accurate, and sufficiently detailed manner. ${ }^{34}$ Article 7 provides that if a state has evidence of an unexpected or

30 Asian Agricultural Products Ltd. v Republic of Sri Lanka, ICSID Case No. ARB/87/3, Final Award, ๆ 76 (June 27, 1990), 4 ICSID Rep. 246 (1997).

31 ILC Report on the Work of its Fifty-third Session, supra note 25, at 34, 93.

32 R. Bagares, China, International Law, and Covid-19, WASH. Post, Feb. 9, 2020, https://www.washingtonpost.com/ world/asia_pacific/chinese-officials-note-serious-problems-in-coronavirus-response-the-world-health-organizationkeeps-praising-them/2020/02/08/b663dd7c-4834-11ea-91ab-ce439aa5c7c1_story.html.

33 IHR art 6(1).

34 Id. art 6(2). 
unusual public health event within its territory that may constitute a public health emergency of international concern, it shall provide the WHO with all relevant public health information. ${ }^{35}$ There is some confusion in the literature regarding the difference between Article 7 and Article 6(1). ${ }^{36}$ However, Article 7 suggest a more precautionary mechanism aimed at strengthening the procedure that was laid down in Article 6(1). Thus, whereas the latter involves the application of the specific decision instrument, the former will be triggered upon mere evidence of a potential health emergency, so that the duty thereunder has no specific time limit.

This specific decision instrument, as included in Annex 2 of the IHR, provides guidance on whether, or at what stage, an event shall be reported to the WHO. Key measurement criteria include: whether the event has a serious impact on public health; whether it would impose a significant risk of international spread, international travel or trade restrictions; and whether it is unusual or unexpected. ${ }^{37}$ However, although Annex 2 contains a non-binding list of examples which aims to assist states in the interpretation of the criteria, the determination of what amounts to "significant risk" or "serious impact," or whether an event is "unusual" or "unexpected," seems to be such an inherently subjective practice that it is impossible to prescribe in precise terms. With regard to a novel virus, in particular, much depends on the scientific and medical capacity of the assessor state, and differences in extra factors such as population density, geography, and climate may lead to different conclusions even for states having the same level of capacity. ${ }^{38}$

In fact, on December 31, 2019, China informed the WHO's China Country Office of cases of pneumonia of unknown etiology detected in Wuhan, ${ }^{39}$ at a time when

35 Id. art. 7.

36 D. Fidler, From International Sanitary Conventions to Global Health Security: The New International Health Regulations, 4 CHINESE J. INT'L L. 365 (2005).

37 IHR, annex 2.

38 M. Moshe \& H. Michael, Explaining Variations in State COVID-19 Responses: Psychological, Institutional, and Strategic Factors in Governance and Public Policy-making, 3 PoL'y Design \& Practice 230 (2020).

39 The following facts are mainly based on the timeline published by the Chinese government. See White Paper on China's Action against the Coronavirus Pandemic (June 2020), State Council Information Office of the People's Republic of China (PRC SCIO), http://www.goven/zhengce/2020-06/07/content_5517737.htm. In order to ensure the veracity of the facts, we have tested this timeline against those published by BBC and the US Congressional Research Service. See Coronavirus: What did China do about early outbreak?, BBC News, June 9, 2020, https://www.bbc.com/ news/world-52573137; COVID-19 and China: A Chronology of Events (Dec. 2019-Jan. 2020), (May 13, 2020), https:// crsreports.congress.gov/product/pdf/R/R46354?_cf_chl_jschl_tk_=45817afc1cddac6cb5eac21 aa6314a00c9d111741591677474-0-AQq_Xzu1HjNdDpBCpYwKGdW03Dx6Ayfvs3okpCE0sPJy_gfI_W0QaNM67VXF3fv8b07Qff4QX j9VIc17HALGh5_5s82Mf0s4NmxFAwmyEnhb_LUuX8rdvTRAIGQBm17vD_33dvg_fd3fnODKLaYQAcNC8IUW ggeIeuBxrXOtmlAK9Y57zu8bbtRreFymyg5wq6cwQcpRneagaBiKFEMe5QDdj1BckiNzhFFqwukcbU0g4SS2esf32 VueFUCu2wN1eenmJbZcmHe8yXTVoqlbKASXQDauUsqS1OkpWO66ot9Q. 
therewere 27 cases identified. ${ }^{40}$ From January 3, 2020 onwards, China has consistently reported to the $\mathrm{WHO}$ about the increasing number of identified cases as well as measures and advancements in identifying the cause of the outbreak. ${ }^{41}$ On January 7 , 2020, the Chinese Center for Disease Control and Prevention successfully isolated and identified the causal agent, a new type of coronavirus. On January 9, immediately after the Expert Evaluation Group of the National Health Commission confirmed the outbreak, China officially notified the WHO of the existence of a potential public health emergency of international concern.

These facts neatly fit into the staggered requirements of Articles 6 and 7 of the IHR. It is apparent that the specific decision instrument as provided in the IHR requires the state to run through a vigilant assessment before notifying the $\mathrm{WHO}$, the outcome of which may have a significant impact on global travel and trade. This assessment inevitably requires a massive amount of resources and time for information collection, verification, and analysis. Indeed, the distinction between Articles 6 and 7 clearly indicates that the time lag between a state's official notification and the emergence of a virus is an in-built presumption of the IHR. Viewed in this light, it is difficult to see what and how China could have violated its obligations under the instrument.

\section{The Role of International Law in the Context of Global Pandemic}

The above section has discussed the potential obligations of China under general international law and the IHR. But the current wave of demanding China be held accountable also evinces a troubling tendency of manipulating international law to achieve ulterior political agendas. Notably, the outbreak of Covid-19 in Wuhan has been a golden opportunity for those critics to vent their dissatisfaction on China's political system or to diminish China's economic and diplomatic influence. Thus, in an attempt to try China in the ICJ by virtue of Article 75 of the WHO Constitution, which provides that disputes relating to the interpretation or application of the Constitution shall be referred to the ICJ if they are not settled by negotiation or by the Health Assembly. Tzeng indicates that suing China could lead to "significant

40 WHO, Novel Coronavirus (2019-nCoV) Situation Report-1 (Jan. 21, 2020), https://www.who.int/docs/default-source/ coronaviruse/situation-reports/20200121-sitrep-1-2019-ncovpdf.

41 PRC SCIO, supra note 39. 
political victories" even if the arguments that China has violated some provisions of the WHO Constitution do not actually hold water. ${ }^{42}$ Kraska goes even further when he proposes, on the basis of what he perceives as lawful countermeasures, a range of Cold War-style political actions against China, which include, inter alia, broadcasting the ineptness and corruption of the Chinese Communist Party throughout China, undermining China's Internet firewall, ensuring that Taiwanese media voices and officials are heard in mainland China, and removing China from leadership positions and even memberships in international organizations. ${ }^{43}$

In order to trigger the application of Article 75, it must be shown that China has violated its obligations of the WHO Constitution. Tzeng cites Articles 21, 22, 37, 63, and 64 as potential bases for holding China responsible. ${ }^{44}$ Most of his arguments are based on the presumption that China has violated its obligations under the IHR, which, as analyzed above, cannot be sustained. Even if this presumption was justified, however, it is difficult to see how violation of the IHR can be even remotely related to: the authority of the Health Assembly to adopt regulations (Article 21); the binding nature of these regulations (Article 22); the duty not to influence the officials of the WHO (Article 37); and the manner in which member states shall provide reports to the organization (Article 64). At times, Tzeng seems to indulge in word-twisting. For instance, referring to Article 63, which requires member states to communicate "published" official reports and statistics with the WHO, Tzeng raises the possibility that posts by Chinese doctors on social media could be taken as "published official reports and statistics." "If following this interpretation, any state where a new virus has emerged must, in order to fulfill its obligation under Article 63, meticulously search for doctors' Twitter replies, Facebook posts, and chat records in WeChat groups and communicate them to the WHO. We wonder whether this interpretation of Article 63 truly reflects the purpose of the global health surveillance system and enhances the efficiency of the pandemic control endeavors.

42 P. Tzeng, Taking China to the International Court of Justice over COVID-19, EJIL: Talk! (Apr. 2, 2020), https://www. ejiltalk.org/taking-china-to-the-international-court-of-justice-over-covid-19.

43 J. Kraska, China Is Legally Responsible for Covid-19 Damage and Claims Could Be in the Trillions, War on the Rocks (23 Mar. 2020), https://warontherocks.com/2020/03/china-is-legally-responsible-for-covid-19-damage-and-claimscould-be-in-the-trillions. Other measures proposed include reversing China's entry into the WTO, suspending air travel to China for a period of years, broadcasting Western media in China, reporting on Chinese coercion against is neighbours in the South China Sea and East China Sea, and ensuring that Chinese people understand the responsibility of the Chinese Communist Party in unleashing a global contagion. In a similar vein, Yoo and Stradner resort to what they call self-help measures ranging from excluding Chinese scholars and students from scientific community to expropriating assets of Chinese companies. See J. Yoo \& I. Stradner, How to Make China Pay, Nat'L Rev., Apr. 6, 2020, https://www.nationalreview.com/2020/04/how-to-make-china-pay.

44 Tzeng, supra note 42.

45 Id. 
As to countermeasures, Kraska justifies his argument by citing the Draft Articles on State Responsibility, which does not prohibit states that are taking countermeasures from violating obligations unrelated to the prior breach. ${ }^{46}$ However, he readily ignores the fact that countermeasures are in essence of a protective or remedial character, not a punitive one. ${ }^{47}$ Indeed, the ILC has repeatedly emphasized in its commentary on the Draft Articles on State Responsibility that countermeasures, which are subject to the principle of necessity and proportionality, are intended not to punish but to induce compliance $^{48}$ and thus operate "as a shield rather than a sword." 49

With respect to membership in international organizations, the ICJ ruled in Interim Accord that Greece's objection to Macedonia's admission to the North Atlantic Treaty Organization cannot be justified on the grounds of countermeasures because it was not taken for the purpose of achieving the cessation of Macedonia's unlawful use of the symbol previously used on its flag, even though both obligations arose from the same treaty. ${ }^{50}$ Viewed from this perspective, it is hard to see how Kraska's actions, many of which are frankly aimed at toppling the Communist Party, could be remotely related to an alleged violation by China of its obligations under the IHR. Countermeasures have always been a controversial topic due to their historical association with power politics and the lack of investigative and enforcement authority in international law. ${ }^{51}$ In any case, Kraska's argument demonstrates to the fullest extent how this institution could be abused to achieve an ulterior political agenda.

Both Tzeng and Kraska's approaches are even more problematic in the field of international health law. Unlike disputes concerning territorial sovereignty or maritime entitlements, which are largely of a "zero-sum" character in the sense that whatever is gained by one side is lost by the other, international health law is essentially, if not exclusively, cooperative in nature. Indeed, the history of international health law is a constant process for expanding universalism and developing normative or institutional frameworks to better facilitate international cooperation in improving the level of health for all people. ${ }^{52}$ Since the adoption of

46 ILC Report on the Work of its Fifty-third Session, supra note 25, a 129, 15.

47 J. Crawford, State Responsibility: The General Part 688 (2013).

48 ILC Report on the Work of its Fifty-third Session, supra note 25, at 129, ๆ 6; 130, ๆ 1; 131, ๆ 7 \& 9; and 135, 7.

49 Id. at $71, \boldsymbol{q} 2$.

50 Application of the Interim Accord of 13 September 1995 (former Yugoslav Republic of Macedonia v. Greece), Judgment, 2011 I.C.J. Rep. 644, ๆ 164 (Dec. 5).

51 Countermeasures were traditionally called reprisals which, as one way of self-help, precluded the wrongfulness even of use of force. For details on reprisals, see S. Darcy, Retaliation and Reprisal, in THE OXford HandBook of the UsE OF ForCe IN INTERNATIONAL LAW 880-96 (M. Weller ed., 2015).

52 For details on the historical evolution of international health law, see M. Mbengue, Public Health, International 
the first international sanitary convention in 1892, there has been literally no treaty concluded in the supervening 128 years that imposes a duty to compensate on states from which a pathogen originates. Although many sanitary treaties (including IHR) contain a dispute settlement mechanism, ${ }^{53}$ no state has ever used these mechanisms to hold other states responsible. Confrontation between states has never been the focus of international endeavors to control infectious diseases.

The detection, verification, and management of new pathogens, which may emerge in every corner of the world, are heavily dependent on the scientific and financial capability of a state and may prove challenging, as evidenced by the severity of the Covid-19 outbreak in the developed world, even for the most sophisticated governance systems. This reality creates what Fidler aptly terms "a shared interest among states" not to resort to confrontational measures regarding a pandemic outbreak. ${ }^{54}$ A state that pointed fingers at others yesterday may find itself on the wrong end of the accusation when a new virus emerges on its own territory tomorrow. Yet, in this process of mutual accusation, political trust between states is dampened at a time when coordinated efforts of the world are needed the most. Immediately after several US domestic lawsuits were initiated against the Chinese central and local governments, ${ }^{55}$ counter-proceedings were brought in Wuhan ${ }^{56}$ and Beijing $^{57}$ against Washington for its botched response to the outbreak of the pandemic. Finally, the "blame Covid-19 on China" rhetoric has largely led to the US suspension of its funding to, as well as its exit from, the WHO, which has repeatedly praised China for its response to the pandemic. ${ }^{58}$

It is difficult to see how these developments could be of any help for the containment of the pandemic, which is by nature a global cause. Although holding China

Cooperation, Max Planck Encyclopedia of Public International Law (R. Wolfrum ed., 2010), https://opil.ouplaw. com/view/10.1093/law:epil/9780199231690/law-9780199231690-e527?prd=EPIL.

53 IHR, art 56.

54 D Fidler, Covid-19 and International Law: Must China Compensate Countries for the Damage?, Just Security, Mar. 27 2020, https://www.justsecurity.org/69394/covid-19-and-international-law-must-china-compensate-countries-for-thedamage-international-health-regulations.

55 The most notable one seems to be initiated by the state of Missouri. See J. Harper, Coronavirus: Missouri Sues Chinese government over Virus Handling, BBC NEws, Apr. 22, 2020, https://www.bbc.com/news/business-52364797.

56 See Wuhan Law Society Sued the US Government for The Epidemic, SINA NEws, Mar. 3, 2020, https://k.sina.cn/article 2662090253_9eac460d01900lvbj.html.

57 See Chinese Lawyers Sue U.S. over 'Coronavirus Cover-up, Radio Free AsIA, Mar. 26, 2020, https://www.rfa.org/ english/news/china/wuhan-lawsuit-03262020122653.html?searchterm:utf8:ustring=\%20Chinese\%20Lawyers.

58 WHO, Press Briefing on WHO Mission to China and Novel Coronavirus Outbreak (Jan. 29, 2020), https://www.who. $\mathrm{int} /$ director-general/speeches/detail/press-briefing-on-who-mission-to-china-and-novel-coronavirus-outbreak. See also S. Nebehay \& E. Farge, WHO lauds Chinese response to virus, says world “at important juncture,"' Reuters, Jan. 30, 2020, https://www.reuters.com/article/us-china-health-who-idUSKBN1ZS2EE. 
responsible for the outbreak of the pandemic by the malicious manipulation of international law is a political victory, the whole world should bear the cost that the two powers may never cooperate in vaccine development, epidemiological research, or data-sharing. The former British Prime Minister Gordon Brown addressed at this juncture:

This is a global problem, not just a national problem. It needs global action and not simply national action. We've had too much of America first, India first, China first. We have had too much of this populist nationalism. We are finding that we are connected whether we like it or not. We are finding that we are depending on each other whether we like it or not. I think people have got to put aside the differences they have, as international cooperation is absolutely vital for this. ${ }^{59}$

International health law is arguably the most apolitical subfield of public international law, and it is immoral, to say the least, to politicize it.

That, of course, is not to say that state parties can willingly violate their obligations under the IHR. It is also obvious that China's handling of the outbreak of Covid-19 is in no way "perfect." However, any potential responsibility can only be established by an impartial third-party investigation based on scientific evidence. While the virus is still raging, any such investigation should be postponed until the pandemic is brought under control. Indeed, both $\mathrm{China}^{60}$ and the $\mathrm{WHO}^{61}$ have signaled that they are open to such an investigation. Conducted in an impartial and transparent manner, the outcome of the investigation would no doubt help the world better prepare for the next pandemic.

\section{Conclusion}

Covid-19 strikes at a time when multilateralism is in retreat and the US-China relationship is at a decades-low. In light of this reality, it is perhaps not surprising, albeit regrettable, that the pandemic has come to the forefront of political attack or

59 L. Buchan, Coronavirus: Gordon Brown Says Too Much 'Populist Nationalism' in Fight against Outbreak, INDEPENDENT, Mar. 19, 2020, https://www.independent.co.uk/news/uk/politics/coronavirus-uk-cases-update-gordonbrown-populist-nationalism-a9410496.html\#gsc.tab=0.

60 R. Picheta, China Backs Coronavirus Investigation but Says It Should Wait until Pandemic is Contained, CNN, May 18, 2020, https://edition.cnn.com/2020/05/18/health/world-health-assembly-china-inquiry-intl/index.html.

61 R Picheta, WHO Approves Call for Inquiry into Global Coronavirus Response, CNN, May 19, 2020, https://edition. cnn.com/2020/05/19/china/wha-pandemic-inquiry-resolution-vote-intl/index.html. 
even racial abuse. ${ }^{62}$ Due to the ambiguous nature, international law, which largely results from its consensual and decentralized character, used to be a tool for political manipulation by one side. However, this ambiguity can also make international law contain broader areas of global governance for the purpose of de-escalating tensions, inducing cooperation, and maintaining peace and stability. Much depends on how international law is actually utilized; and in order to well face the challenges from the new political environment, international lawyers should maintain at least a minimum amount of restraint and objectivity for its interpretation. China's broadly worded policy objectives, such as building "a community of shared future for mankind" are often snubbed in the West as propagandist political slogans devoid of meaningful substance. ${ }^{63}$ However, the underlying spirit they embody is nonetheless highly compatible with the basic tenets of international law. Unfortunately, at a time of heightened political tensions, these basic tenets are not so plain to see.

Received: February 1, 2021

Modified: March 30, 2021

Accepted: May 15, 2021

62 Referring to the Chinese eating habits, Tzouvala, for instance, speaks of Asian and Chinese "backwardness, primitiveness and (economic, cultural, moral) under-development." See N. Tzouvala, COVID-19 Symposium: The Combined and Uneven Geography of COVID-19, or on Law, Capitalism and Disease, OpinIo Juris, Apr. 2, 2020, http://opiniojuris.org/2020/04/02/covid-19-symposium-the-combined-and-uneven-geography-of-covid-19-or-on-lawcapitalism-and-disease.

63 Z. Jinghan, Slogan of "Community of Shared Future for Mankind," in Slogan Politics: Understanding Chinese Foreign Policy Concepts 111-30 (2020). See also J. Mardell, The "Community of Common Destiny" in Xi Jinping's New Era, Diplomat, Oct. 25, 2017, https://thediplomat.com/2017/10/the-community-of-common-destiny-in-xijinpings-new-era. 